\title{
Letter Code System of Nomenclature for Puccinia graminis f. sp. avenae
}

\author{
T. G. Fetch, Jr., Cereal Research Centre, Agriculture and Agri-Food Canada, Winnipeg, MB R3T 2M9, Canada; and \\ Y. Jin, Cereal Disease Laboratory, United States Department of Agriculture-Agricultural Research Service, Univer- \\ sity of Minnesota, St. Paul 55108
}

\begin{abstract}
Fetch, T. G., Jr., and Jin, Y. 2007. Letter code system of nomenclature for Puccinia graminis f. sp. avenae. Plant Dis. 91:763-766.

Current systems that describe the virulence phenotype in Puccinia graminis f. sp. avenae lack a systematic approach for the naming of races or to provide easily made comparisons of virulence among races. A new nomenclature system that simply and systematically characterizes virulence in $P$. graminis f. sp. avenae is described. The new system has the distinct advantage of providing easily seen relationships among races in contrast to previous nomenclature systems. This allows for easier interpretation of virulence relationships in the oat stem rust population and provides a large amount of virulence information with a minimum of written characters. This system uses single-gene differential lines with the resistance genes $P g 1, P g 2, P g 3, P g 4, P g 6, P g 8, P g$, $P g 10, P g 12, P g 13, P g 15$, and $P g 16$, grouped into three subsets of four lines in sequential $P g$ gene order. By grouping in sequential gene number order, the relationship of the new system to the "standard" system is easily seen. Each race is designated by a three-letter code, based on the seedling reaction (low or high) on 12 differential lines. The letter code nomenclature system is open ended and can be updated easily as new differential genes are identified. This system simply and precisely describes the virulence phenotypes of isolates of $P$. graminis $\mathrm{f}$. sp. avenae, and allows for easily made comparisons of virulence of isolates collected over time and across geographical locations worldwide.
\end{abstract}

Several nomenclature systems to describe virulence in Puccinia graminis f. sp. avenae Erikss. \& Henning have been developed; however, currently, there is no adequate system that simply describes the virulence phenotypes of isolates of $P$. graminis f. sp. avenae or provides easily made comparisons of virulence of isolates from different geographical areas. Physiologic specialization in $P$. graminis $\mathrm{f}$. $\mathrm{sp}$. avenae first was described by Stakman et al. in 1923 using the varieties Victory, White Tartar, and Monarch to describe four races of oat stem rust (20). In 1925, Bailey described five races of $P$. graminis $\mathrm{f}$. sp. avenae, using White Tartar (=White Russian), Richland, and Jostrain (3). Levine and Smith added races 6 to 10 in 1937, and Newton and Johnson added races 11 to 13 in 1944, using the same three differential

Corresponding author: T. G. Fetch, Jr.

Email: tfetch@agr.gc.ca

This is contribution no. 1943 of the Cereal Research Centre.

Accepted for publication 6 January 2007.

doi:10.1094/PDIS-91-6-0763

Department of Agriculture and Agri-Food, Government of Canada () Minister of Public Works and Government Services Canada 2007 varieties $(11,16)$. These first 13 races were used as the standard for describing physiologic specialization in $P$. graminis $\mathrm{f}$. $\mathrm{sp}$. avenae.

Subsequent to the description of the 13 "standard" races, additional genes conferring resistance to $P$. graminis $\mathrm{f}$. $\mathrm{sp}$. avenae were found and are described in Table 1. Genes originally were designated by using a letter (e.g., gene $A$ ) but currently are designated by number (e.g., $P g 2$ ) using a standardized gene nomenclature system (19). Deviations from standard races were described as subraces, adding letters to standard race numbers to identify additional races. In 1965, Green (7) devised a virulence formula nomenclature system for Canada (C-races) using genes from the differential varieties Richland, Rodney, Minrus, Jostrain, CI 4023, and CI 5844-1. In 1970, Stewart and Roberts published the first proposed international system for identifying races of $P$. graminis $\mathrm{f}$. $\mathrm{sp}$. avenae, using the same six differential varieties as Green (7) and the diploid oat line Saia to describe the "standard" races, numerous subraces, $\mathrm{C}$-races, and exotic races from several countries, with a total of 97 races identified (21).

The development of backcross-derived lines (Rodney 0 background) with a single gene ( $P g$ gene) for oat stem rust resistance led to the development of the North
American (NA) nomenclature system in 1979 (14), which currently is used to characterize virulence in $P$. graminis f. sp. avenae in Canada and the United States. In contrast, virulence in $P$. graminis f. sp. avenae in Australia currently is characterized using a modified Stewart and Roberts system (2). Because there is a lack of continuity across the various nomenclature systems and there appears to be no systematic approach in the naming of races (other than by order of discovery), we describe a new nomenclature similar to existing cereal rust nomenclature systems $(4,12,17)$ that simply and precisely identifies the virulence phenotype (race) of isolates of $P$. graminis $\mathrm{f}$. sp. avenae. This system will provide a method to easily and accurately compare virulence of isolates collected over time and across geographical areas.

\section{THE LETTER CODE RACE NOMENCLATURE SYSTEM}

Currently, there are 17 numbered $\mathrm{Pg}$ genes identified, plus the $P g-a$ complex. Genes $P g 5$ and $P g 7$ are repetitive of genes $P g 4$ and $P g 6$, respectively, and are of no use as differential lines (13). Genes $P g 11$ and $P g 17$ are expressed only at the adult plant stage and would not be useful as differential lines at the seedling stage $(10,15)$. Gene $P g 14$ is ineffective to numerous North American and exotic isolates tested thus far (T. Fetch, unpublished data) and is not noted for its resistance (13); thus, it is not included in the differential set. All other numbered genes are useful in characterizing virulence and are included in the differential sets.

The differential lines for the new nomenclature system are listed in Table 2. Most $(P g 1, P g 2, P g 3, P g 8, P g 9, P g 13$, $P g 15$, and $P g 16)$ are in a Rodney 0 (CI 9317, no known $P g$ resistance gene) background as described by Martens et al. (14). Comparisons of infection type (IT) between original sources of resistance to their Rodney 0-derived lines were made with several races using previously reported methods (5), and the results are presented in Table 3. IT of infected seedlings was determined using a 0-to-4 scale, where ITs of $0, ;, 1$, and 2 , or combinations thereof, are classified as low ITs and indicative of resistance, whereas ITs of 3 or 
4 are high ITs and indicative of susceptibility (3). Because expression of several $P g$ genes is affected by incubation temperature $(6,14)$, all comparisons were conducted in a growth chamber at $19^{\circ} \mathrm{C}$ with a 16-h photoperiod and light intensity of 180 to $220 \mu \mathrm{mol}$ photon $\mathrm{m}^{2} \mathrm{~s}^{-1}$. Under these incubation conditions, all genes will express their low ITs to avirulent races of $P$. graminis f. sp. avenae, which is easily discernable from a susceptible (IT 34 or 4) reaction. For a given $P g$ gene, the observed ITs between the original source and the corresponding Rodney line were comparable (Table 3). However, it was found that several $P g$ gene sources and their Rodney 0 derivatives acquired from the Unites States Department of AgricultureAgricultural Research Service (USDAARS) National Small Grains Collection (NSGC) in Aberdeen, ID were mixed for ITs. Therefore, differential lines in the Rodney 0 background were reselected for the correct phenotype and increased for seed that is available for race identification of $P$. graminis f. sp. avenae.

The letter code nomenclature utilizes 12 single-gene $P g$ differential lines, using three subsets of four lines organized into a hexadecimal system that has 16 possible combinations of low $(\mathrm{L})$ or high $(\mathrm{H})$ reaction for each letter (Table 4). This is adapted from the existing nomenclature systems used for other cereal rusts $(4,12,17)$. The advantage of the letter code system is a simple, short, and accurate description of virulence phenotype across most of the described resistance genes, which enables utilization of this system regardless of when and where isolates have been collected. In contrast, comparisons of virulence of isolates identified using the "standard", C number, and NA formula system were difficult and imprecise (8), due to the lack of a systematic approach in numbering of races and to addition of differential lines that occurred over time. Because the order of genes in the new system is sequential, it is relatively easy to make comparisons to the "standard" system originally described (e.g., race $1=\mathrm{B}_{-}$ or $C_{-}$races, race $2=D_{-}$races, race $\overline{6}$ group $=\mathrm{TG}_{-}$or $\mathrm{TD}_{-}$races, race 7 group $=$ $\mathrm{N}_{-}$or $\mathrm{P}_{-}$races, race $8=\mathrm{J}_{-}$races, and race 11 group $=G_{-}$or $H_{-}$races $)$. Additionally, virulence of isolates collected worldwide cannot currently be compared, because differential sets are not uniform and different nomenclature systems are utilized. The letter code system is flexible in that, as new $P g$ genes are characterized, they can be added as additional subsets and letters appended accordingly. Data on supplemental lines can be added to the letter code using a plus (+) sign (e.g., race TGL+ $P g$ $a$ ). In addition, the letter code system is suitable for international use because it incorporates almost all $P g$ genes to characterize virulence in $P$. graminis $\mathrm{f}$. sp. avenae. Virulence information previously reported in North America is presented in Table 5 using the new letter code, NA number designation (14), and avirulence or virulence formula systems. Each NA race reported previously corresponded to a unique letter-code race designation following this system.

The new system uses three seedling $P g$ genes ( $P g 6, P g 10$, and $P g 12)$ that have not been used previously to characterize $P$. graminis f. sp. avenae. Gene $P g 6$ (from CI 6956) and the resistance gene in the diploid line Saia (which is used in the Stewart and Roberts nomenclature) appear to be identical (18). Although Pg6 has not yet been transferred into a hexaploid background, it has been shown to be useful in differentiating isolates of stem rust at the Winnipeg Rust laboratory. In testing of 23 common North American races stored at

Table 2. Differential lines used for characterizing virulence in Puccinia graminis f. sp. avenae ${ }^{\mathrm{a}}$

\begin{tabular}{|c|c|c|c|c|c|}
\hline$P g$ gene & CI no. & CN no. & RL no. & IT at $20^{\circ} \mathrm{C}^{\mathrm{b}}$ & Source of resistance \\
\hline Pgl & 9318 & 58243 & 899 & $11^{+}$ & White Russian, CI 551 \\
\hline Pg2 & 9319 & 58244 & 815 & $; 1$ & Hajira, CI 1001 \\
\hline Pg3 & 2660 & 58245 & & $; 1$ to $\mathrm{X}^{-}$ & Jostrain, CI 2660 \\
\hline Pg4 & 6661 & 56534 & 2123 & $; 1^{-}$ & Hajira, CI 1001 \\
\hline Pg6 & 6956 & 56818 & & $0 ; 1^{-}$ & CD 3820, CI 6956 \\
\hline $\operatorname{Pg} 8$ & 9321 & 58246 & 903 & $12^{-}$ & Hajira, CI 8111 \\
\hline $\operatorname{Pg} 9$ & 9322 & 58247 & 879 & $11^{+}$ & CI 6792 \\
\hline Pg10 & 8457 & 58055 & $\ldots$ & $23 n$ & Illinois Hulless, CI 2824 \\
\hline $\operatorname{Pg} 12$ & 8250 & 64102 & $\ldots$ & $; 1$ & Kyto, CI 8250 \\
\hline Pg13 & 9212 & 28959 & 618 & $11^{+}$ & Avena sterilis, PI 324798 \\
\hline Pg15 & 9351 & 58276 & 997 & $11^{+}$ & A. sterilis, CAV 1830 \\
\hline Pg16 & 9352 & 58277 & 882 & $12^{-}$ & A. barbata, D203 \\
\hline$P g-a$ & $\ldots$ & 1947 & 996 & $0 ; 1^{-}$ & Omega, CI 9139 \\
\hline
\end{tabular}

${ }^{a} \mathrm{CI}$ is the Cereal Introduction number (United States Department of Agriculture-Agricultural Research Service, Aberdeen, ID), CN is the Canadian Number (Plant Genetic Resources Collection, Saskatoon, SK, Canada), and RL is the Rust Lab accession number (Cereal Rust Lab, Winnipeg, MB, Canada).

${ }^{\mathrm{b}}$ Infection types (ITs) are based on a 0-to-4 scale (3).

Table 1. Background information for resistance genes to Puccinia graminis f. sp. avenae

\begin{tabular}{|c|c|c|c|c|c|c|c|}
\hline$P g$ gene & Letter $^{\mathbf{a}}$ & Year & Origin & Source & Avena sp. & CI number & Temperature $^{b}$ \\
\hline 1 & $\mathrm{D}$ & 1925 & Russia & White Russian & sativa & 551 & None \\
\hline 1 & $\mathrm{D}$ & 1938 & Russia & Minrus & sativa & 2144 & None \\
\hline 2 & A & 1925 & Russia & Richland & sativa & 787 & None \\
\hline 3 & $\mathrm{E}$ & 1925 & USA & Sevnothree & sativa & 3251 & $21^{\circ} \mathrm{C}$ \\
\hline 3 & $\mathrm{E}$ & 1925 & France & Jostrain & sativa & 2660 & $21^{\circ} \mathrm{C}$ \\
\hline 4 & $\mathrm{~B}$ & 1954 & South Africa & Hajira & sativa & 1001 & $26^{\circ} \mathrm{C}$ \\
\hline 5 & $\mathrm{C}$ & 1954 & South Africa & Hajira & sativa & 4019 & $\ldots$ \\
\hline 6 & $\ldots$ & 1956 & Uruguay & CD 3820 & strigosa & 6956 & None \\
\hline 7 & $\ldots$ & 1956 & Uruguay & CD 3820 & strigosa & 6956 & $\ldots$ \\
\hline 8 & $\mathrm{~F}$ & 1959 & North Africa & Hajira & sativa & 8111 & $27^{\circ} \mathrm{C}$ \\
\hline 9 & $\mathrm{H}$ & 1965 & Argentina & Sante Fe selection & sativa & $5844-1$ & $25^{\circ} \mathrm{C}$ \\
\hline 10 & G & 1965 & USA & Illinois Hulless & nuda & 2824 & None \\
\hline 11 & $\ldots$ & 1968 & Rhodesia & Burt & sativa & 3034 & Adult $^{\mathrm{c}}$ \\
\hline 12 & $\ldots$ & 1968 & Yugoslavia & Kyto & sativa & 8250 & $25^{\circ} \mathrm{C}$ \\
\hline 13 & $\mathrm{M}$ & 1970 & Tunisia & CW490-2 & sterilis & PI 324798 & $27^{\circ} \mathrm{C}$ \\
\hline 14 & $\mathrm{~N}$ & 1972 & Wales & Milford & sativa & 5039 & \\
\hline 15 & $\ldots$ & 1980 & Turkey & CAV 1830 & sterilis & 9351 & $26^{\circ} \mathrm{C}$ \\
\hline 16 & $\mathrm{R}$ & 1979 & Israel & D-203 & barbata & 9125 & $25^{\circ} \mathrm{C}$ \\
\hline 17 & $\ldots$ & 1990 & Spain & IB 3056 & sterilis & $\ldots$ & Adult \\
\hline$P g-a$ & $\mathrm{X}$ & 1981 & USA & Omega & hybrid & 9139 & $26^{\circ} \mathrm{C}$ \\
\hline
\end{tabular}

\footnotetext{
${ }^{a}$ Genes originally were designated by letter, then changed later to a $P g$ gene number (17).

${ }^{\mathrm{b}}$ Incubation of lines at or above this temperature renders ineffective the expression of resistance (6). For genes $P g 1, P g 2, P g 6$, and $P g 10$, there is no effect of incubation temperature up to $30^{\circ} \mathrm{C}$.

${ }^{c}$ CI 3034 also has been reported to possess the seedling gene $P g 1$ (11).
} 
the Winnipeg Rust Laboratory, only NA1 and NA70 have been found to be virulent on Pg6 (T. Fetch and Zegeye, unpublished data); thus, most North American races were presumed to be avirulent to $P g 6$ in Table 5. In contrast, virulence to Saia $(=P g \sigma)$ is observed frequently in isolates of $P$. graminis $\mathrm{f}$. sp. avenae in Australia (2).

Gene Pg10 (from CI 2824) has not been used in previous nomenclature systems due to temperature sensitivity (14). Studies at Winnipeg indicate that the reaction of $\mathrm{Pg} 10$ is intermediate (IT = $23 \mathrm{~N})$ at low $\left(15\right.$ to $21^{\circ} \mathrm{C}$ ) temperatures, but becomes more resistant $(12+\mathrm{N})$ at elevated $\left(>24^{\circ} \mathrm{C}\right)$ temperatures (6). Although $\mathrm{PgIO}$ exhibits an intermediate resistance reaction $(\mathrm{IT}=23 \mathrm{n})$, the distinct necrosis associated with its resistance response is unique to this gene (9) and is easily discernable from a susceptible (IT $=3$ or 4) reaction. Virulence to $P g 10$ has not been observed in North America among several thousand isolates tested at Winnipeg and St. Paul rust laboratories, but virulence to $\mathrm{Pg} 10$ has been found from an isolate obtained from New Zealand (T. Fetch, unpublished data).

Gene $P g 12$ has not been used previously in nomenclature systems, but the related $P g$ - $a$ complex was used by Martens et al. (14) in the NA nomenclature. Gene PgI2 is included in the new differential set in lieu of the Pg- $a$ complex because (i) it is a single gene, (ii) no differential response (high versus low) between $P g 12$ and $P g-a$ has been found among several thousand isolates tested simultaneously on the two lines, and (iii) allelism tests of $F_{2}$ progeny from crosses between the $\mathrm{Pg} 12$ source
'Kyto' (CI 8250) and Pg-a source 'Omega' (CI 9139) found no susceptible segregants among $4495 \mathrm{~F}_{2}$ plants (T. Fetch, unpublished data). Thus, the low seedling IT observed on the $P g$ - $a$ complex apparently is conditioned by the gene $P g 12$ and may be modified by an additional unknown recessive gene. This is in contrast to previously published data that reported that $P g 12$ is not involved in the $P g-a$ response (1). The $P g$ - $a$ complex was included in Table 2 as a supplementary line because of historical use, but is not intended as a differential line in this nomenclature system.
The letter code nomenclature system presented here is simple, precise, and describes the virulence spectrum of races of $P$. graminis f. sp. avenae on most known seedling resistance genes in oat. This system will be useful in enabling rust workers to uniformly characterize $P$. graminis $\mathrm{f}$. sp. avenae isolates for discussion on virulence dynamics and population studies. Limited seed for all differential lines is available from the authors, and also from seed depositories in Plant Gene Resources Canada (PGRC, Saskatoon, SK) and USDA-ARS NSGC in Aberdeen, ID.

Table 4. Letter code designations for races of Puccinia graminis $\mathrm{f}$. sp. avenae using 12 differential single $P g$-gene lines in three ordered subsets of four lines each

\begin{tabular}{|c|c|c|c|c|c|}
\hline \multirow[b]{4}{*}{ Letter code } & \multirow{2}{*}{$\frac{\text { Subset }}{1}$} & \multicolumn{4}{|c|}{ Classification of infection types (ITs) ${ }^{a}$} \\
\hline & & Pg1 & $\operatorname{Pg} 2$ & Pg3 & $\operatorname{Pg} 4$ \\
\hline & 2 & Pg6 & $\operatorname{Pg} 8$ & $\operatorname{Pg} 9$ & Pg10 \\
\hline & 3 & Pg12 & Pg13 & Pg15 & Pg16 \\
\hline B & $\ldots$ & $\mathrm{L}$ & $\mathrm{L}$ & $\mathrm{L}$ & $\mathrm{L}$ \\
\hline $\mathrm{C}$ & $\ldots$ & $\mathrm{L}$ & $\mathrm{L}$ & $\mathrm{L}$ & $\mathrm{H}$ \\
\hline $\mathrm{D}$ & $\ldots$ & $\mathrm{L}$ & $\mathrm{L}$ & $\mathrm{H}$ & $\mathrm{L}$ \\
\hline $\mathrm{F}$ & $\ldots$ & $\mathrm{L}$ & $\mathrm{L}$ & $\mathrm{H}$ & $\mathrm{H}$ \\
\hline $\mathrm{G}$ & $\ldots$ & $\mathrm{L}$ & $\mathrm{H}$ & $\mathrm{L}$ & $\mathrm{L}$ \\
\hline $\mathrm{H}$ & $\ldots$ & $\mathrm{L}$ & $\mathrm{H}$ & $\mathrm{L}$ & $\mathrm{H}$ \\
\hline $\mathrm{J}$ & $\ldots$ & $\mathrm{L}$ & $\mathrm{H}$ & $\mathrm{H}$ & $\mathrm{L}$ \\
\hline $\mathrm{K}$ & $\ldots$ & $\mathrm{L}$ & $\mathrm{H}$ & $\mathrm{H}$ & $\mathrm{H}$ \\
\hline $\mathrm{L}$ & $\ldots$ & $\mathrm{H}$ & $\mathrm{L}$ & $\mathrm{L}$ & $\mathrm{L}$ \\
\hline M & $\ldots$ & $\mathrm{H}$ & $\mathrm{L}$ & $\mathrm{L}$ & $\mathrm{H}$ \\
\hline $\mathrm{N}$ & $\ldots$ & $\mathrm{H}$ & $\mathrm{L}$ & $\mathrm{H}$ & $\mathrm{L}$ \\
\hline $\mathrm{P}$ & $\ldots$ & $\mathrm{H}$ & $\mathrm{L}$ & $\mathrm{H}$ & $\mathrm{H}$ \\
\hline $\mathrm{Q}$ & $\ldots$ & $\mathrm{H}$ & $\mathrm{H}$ & $\mathrm{L}$ & $\mathrm{L}$ \\
\hline $\mathrm{R}$ & $\ldots$ & $\mathrm{H}$ & $\mathrm{H}$ & $\mathrm{L}$ & $\mathrm{H}$ \\
\hline $\mathrm{S}$ & $\ldots$ & $\mathrm{H}$ & $\mathrm{H}$ & $\mathrm{H}$ & $\mathrm{L}$ \\
\hline $\mathrm{T}$ & $\ldots$ & $\mathrm{H}$ & $\mathrm{H}$ & $\mathrm{H}$ & $\mathrm{H}$ \\
\hline
\end{tabular}

a Classification of infection types: $\mathrm{L}=$ low/resistant (ITs of $0, ;, 1$, and 2, or combination thereof) and $\mathrm{H}=$ high/susceptible (ITs of 3,4 , or combination thereof) (17).

Table 3. Infection type (IT) comparison of oat lines with original sources of $P g$ gene resistance and equivalent Rodney 0 -derived lines to races of $P u c c i n i a$ graminis f. sp. avenae

\begin{tabular}{|c|c|c|c|c|c|c|c|}
\hline \multirow[b]{2}{*}{ Pg gene } & \multirow[b]{2}{*}{ CI no. ${ }^{b}$} & \multirow[b]{2}{*}{ Genetic background } & \multicolumn{5}{|c|}{ IT at $20^{\circ} \mathrm{C}^{\mathrm{a}}$} \\
\hline & & & NA1 & NA8 & NA16 & NA20 & NA55 \\
\hline \multirow{2}{*}{$\overline{P g 1}$} & 551 & White Russian & $2^{ \pm}$ & $12^{-}$ & $3+4$ & $3+4$ & $34 n$ \\
\hline & 9318 & Rodney 0 & $12^{-}$ & $1^{ \pm}$ & $3+4$ & 4 & $3^{+} n$ \\
\hline \multirow[t]{2}{*}{$\operatorname{Pg} 2$} & 787 & Richland & $; 1$ & $; 1^{-}$ & $; 1$ & 4 & $34 n$ \\
\hline & 9319 & Rodney 0 & ;1 & $; 1$ & $; 1$ & 4 & $34 n$ \\
\hline \multirow[t]{2}{*}{$\operatorname{Pg} 3$} & 2660 & Jostrain & $\mathrm{X}^{-}$ & $X^{=}$ & 4 & 0 & $X^{=}$ \\
\hline & 9320 & Rodney 0 & $\mathrm{X}^{-}$ & $\mathrm{X}^{-}$ & 4 & 0 & $X^{=}$ \\
\hline \multirow[t]{2}{*}{$P g 4$} & 1001 & Hajira & $; 1$ & $33^{+}$ & $; 1$ & 4 & $34 n$ \\
\hline & 6661 & Rodney & $; 1^{-}$ & $33^{+}$ & $; 1$ & 4 & $34 n$ \\
\hline \multirow[t]{2}{*}{$\operatorname{Pg} 8$} & 8111 & Hajira & $; 1$ & $; 1^{+}$ & 34 & $11^{+}$ & $; 1$ \\
\hline & 9321 & Rodney 0 & $1^{-}$ & $1^{ \pm}$ & $3+4$ & $12^{-}$ & $; 1$ \\
\hline \multirow[t]{2}{*}{$\operatorname{Pg} 9$} & $5844-1$ & Sante Fe select & $11^{+}$ & 4 & $; 1$ & 4 & $34 n$ \\
\hline & 9322 & Rodney 0 & 12 & 4 & $; 1^{+}$ & 4 & $3+4$ \\
\hline \multirow[t]{2}{*}{$\operatorname{Pg} 10$} & 2824 & Illinois Hulless & $3^{ \pm} \mathrm{N}$ & $23^{+} \mathrm{N}$ & $24 \mathrm{~N}$ & $23^{+} \mathrm{N}$ & $13^{-} \mathrm{N}$ \\
\hline & 8457 & $\mathrm{X}-1588$ & $13 \mathrm{~N}$ & $12^{+} \mathrm{N}$ & $23 \mathrm{~N}$ & $12^{+} \mathrm{N}$ & $22^{+} n$ \\
\hline \multirow[t]{2}{*}{$\operatorname{Pg} 13$} & 2647 & A. sterilis & $; 1$ & 34 & $; 1$ & $; 1$ & $; 1$ \\
\hline & 9212 & Rodney 0 & $; 1^{-}$ & 34 & $; 1^{-}$ & $; 1$ & $; 1$ \\
\hline \multirow[t]{2}{*}{$\operatorname{Pg} 15$} & 1830 & A. sterilis & 34 & 34 & $; 1$ & 34 & 34 \\
\hline & 9351 & Rodney 0 & 34 & 34 & $; 1$ & 34 & $23^{+}$ \\
\hline \multirow[t]{2}{*}{$\operatorname{Pg} 16$} & D203 & A. barbata & $1^{-}$ & $; 1^{-}$ & $1^{-}$ & $; 1^{-}$ & 34 \\
\hline & 9352 & Rodney 0 & $11^{-}$ & $; 1$ & $11^{-}$ & $; 1$ & 34 \\
\hline
\end{tabular}

a ITs are based on a 0 -to- 4 scale where ITs of $0, ;, 1$, and 2 are indicative of a resistant (low) response and ITs of 3 or 4 of a susceptible (high) response (3). Symbols + and - indicate slightly larger and smaller pustule sizes, respectively. North American (NA) races use the nomenclature of Martens et al. (14).

b CI is the Cereal Introduction number (United States Department of Agriculture-Agricultural Research Service, Aberdeen, ID). 
Table 5. Key to races of Puccinia graminis f. sp. avenae using the letter code nomenclature, North American (NA) nomenclature, and avirulence/virulence formula system ${ }^{\mathrm{a}}$

\begin{tabular}{|c|c|c|c|c|c|c|c|c|}
\hline Code & Race & Eff/ineff $P g$ genes & Code & Race & Eff/ineff $P g$ genes & Code & Race & Eff/ineff $P g$ genes \\
\hline $\mathrm{BDB}$ & NA38 & $1,2,3,4,8,13,15,16, \mathrm{a} / 9$ & KBD & NA11 & $1,8,9,13,16, \mathrm{a} / 2,3,4,15$ & RBD & NA19 & $3,8,9,13,16, \mathrm{a} / 1,2,4,15$ \\
\hline BDD & NA2 & $1,2,3,4,8,13,16, a / 9,15$ & KDD & NA12 & $1,8,13,16, \mathrm{a} / 2,3,4,9,15$ & RDD & NA20 & $3,8,13,16, \mathrm{a} / 1,2,4,9,15$ \\
\hline BDJ & NA3 & $1,2,3,4,8,16, \mathrm{a} / 9,13,15$ & KDJ & NA32 & $1,8,16, \mathrm{a} / 2,3,4,9,13,15$ & $\mathrm{RDF}$ & NA58 & $3,8,13, \mathrm{a} / 1,2,4,9,15,16$ \\
\hline BLD & NA1 & $1,2,3,4,8,9,13,16, \mathrm{a} / 15$ & KJD & NA13 & $1,13,16, \mathrm{a} / 2,3,4,8,9,15$ & RDJ & NA54 & $3,8,16, \mathrm{a} / 1,2,4,9,13,15$ \\
\hline CDJ & NA4 & $1,2,3,8,16, \mathrm{a} / 4,9,13,15$ & LDD & NA65 & $2,3,4,8,13,16, \mathrm{a} / 1,9,15$ & RGB & NA21 & $3,9,13,15,16, a / 1,2,4,8$ \\
\hline CLD & NA70 & $1,2,3,8,9,13,16, \mathrm{a} / 4,15$ & LGB & NA14 & $2,3,4,9,13,15,16, a / 1,8$ & RGD & NA77 & $3,9,13,16, a / 1,2,4,8,15$ \\
\hline DBB & NA39 & $1,2,4,8,9,13,15,16, \mathrm{a} / 3$ & MDD & NA71 & $2,3,8,13,16, \mathrm{a} / 1,4,9,15$ & RJB & NA51 & $3,13,15,16, a / 1,2,4,8,9$ \\
\hline DBD & NA5 & $1,2,4,8,9,13,16, \mathrm{a} / 3,15$ & MGB & NA44 & $2,3,9,13,15,16, \mathrm{a} / 1,4,8$ & RJD & NA72 & $3,13,16, \mathrm{a} / 1,2,4,8,9,15$ \\
\hline DDD & NA6 & $1,2,4,8,13,16, \mathrm{a} / 3,9,15$ & NBB & NA15 & $2,4,8,9,13,15,16, \mathrm{a} / 1,3$ & RJJ & NA75 & $3,16, \mathrm{a} / 1,2,4,8,9,13,15$ \\
\hline DDJ & NA7 & $1,2,4,8,16, \mathrm{a} / 3,9,13,15$ & NDB & NA45 & $2,4,8,13,15,16, \mathrm{a} / 1,3,9$ & SBD & NA22 & $4,8,9,13,16, \mathrm{a} / 1,2,3,15$ \\
\hline DJD & NA53 & $1,2,4,13,16, \mathrm{a} / 3,8,9,15$ & NDD & NA35 & $2,4,8,13,16, \mathrm{a} / 1,3,9,15$ & SDD & NA61 & $4,8,13,16, \mathrm{a} / 1,2,3,9,15$ \\
\hline FBD & NA56 & $1,2,8,9,13,16, \mathrm{a} / 3,4,15$ & NDJ & NA47 & $2,4,8,16, \mathrm{a} / 1,3,9,13,15$ & SGB & NA23 & $4,9,13,15,16, a / 1,2,3,8$ \\
\hline FDD & NA74 & $1,2,8,13,16, \mathrm{a} / 3,4,9,15$ & NDL & NA46 & $2,4,8,13,15,16 / 1,3,9, \mathrm{a}$ & SGD & NA63 & $4,9,13,16, \mathrm{a} / 1,2,3,8,15$ \\
\hline FDJ & NA8 & $1,2,8,16, \mathrm{a} / 3,4,9,13,15$ & NGB & NA16 & $2,4,9,13,15,16, \mathrm{a} / 1,3,8$ & TBD & NA24 & $8,9,13,16, a / 1,2,3,4,15$ \\
\hline GBD & NA59 & $1,3,4,8,9,13,16, \mathrm{a} / 2,15$ & NGD & NA18 & $2,4,9,13,16, \mathrm{a} / 1,3,8,15$ & TDB & NA52 & $8,13,15,16, a / 1,2,3,4,9$ \\
\hline GDD & NA64 & $1,3,4,8,13,16, \mathrm{a} / 2,9,15$ & NGL & NA17 & $2,4,9,13,15,16 / 1,3,8, a$ & TDD & NA25 & $8,13,16, a / 1,2,3,4,9,15$ \\
\hline GDJ & NA34 & $1,3,4,8,16, \mathrm{a} / 2,9,13,15$ & NJB & NA48 & $2,4,13,15,16, \mathrm{a} / 1,3,8,9$ & TDF & NA55 & $8,13, \mathrm{a} / 1,2,3,4,9,15,16$ \\
\hline HBD & NA69 & $1,3,8,9,13,16, \mathrm{a} / 2,4,15$ & PBD & NA57 & $2,8,9,13,16, \mathrm{a} / 1,3,4,15$ & TDJ & NA26 & $8,16, a / 1,2,3,4,9,13,15$ \\
\hline HDB & NA40 & $1,3,8,13,15,16, \mathrm{a} / 2,4,9$ & PBG & NA66 & $2,8,9,15,16, \mathrm{a} / 1,3,4,13$ & TGB & NA27 & $9,13,15,16, a / 1,2,3,4,8$ \\
\hline HDD & NA9 & $1,3,8,13,16, \mathrm{a} / 2,4,9,15$ & PDB & NA49 & $2,8,13,15,16, \mathrm{a} / 1,3,4,9$ & TGD & NA29 & $9,13,16, a / 1,2,3,4,8,15$ \\
\hline HDJ & NA31 & $1,3,8,16, \mathrm{a} / 2,4,9,13,15$ & PDD & NA36 & $2,8,13,16, \mathrm{a} / 1,3,4,9,15$ & TGL & NA28 & $9,13,15,16 / 1,2,3,4,8, \mathrm{a}$ \\
\hline JBD & NA10 & $1,4,8,9,13,16, \mathrm{a} / 2,3,15$ & PDJ & NA37 & $2,8,16, \mathrm{a} / 1,3,4,9,13,15$ & TJB & NA68 & $13,15,16, \mathrm{a} / 1,2,3,4,8,9$ \\
\hline JDB & NA41 & $1,4,8,13,15,16, \mathrm{a} / 2,3,9$ & QBB & NA73 & $3,4,8,9,13,15,16, \mathrm{a} / 1,2$ & TJD & NA30 & $13,16, \mathrm{a} / 1,2,3,4,8,9,15$ \\
\hline JDD & NA33 & $1,4,8,13,16, \mathrm{a} / 2,3,9,15$ & QBD & NA60 & $3,4,8,9,13,16, \mathrm{a} / 1,2,15$ & TJG & NA76 & $15,16, \mathrm{a} / 1,2,3,4,8,9,13$ \\
\hline JDJ & NA42 & $1,4,8,16, \mathrm{a} / 2,3,9,13,15$ & QDD & NA62 & $3,4,8,13,16, \mathrm{a} / 1,2,9,15$ & TJJ & NA67 & $16, \mathrm{a} / 1,2,3,4,8,9,13,15$ \\
\hline $\mathrm{KBB}$ & NA43 & $1,8,9,13,15,16, \mathrm{a} / 2,3,4$ & QGB & NA50 & $3,4,9,13,15,16, \mathrm{a} / 1,2,8$ & & & \\
\hline
\end{tabular}

${ }^{\text {a }}$ Code $=$ letter code, Race $=$ NA race, and Eff/ineff $=$ effective/ineffective. The letter code system infers that reaction to $P g 12$ is identical to $P g$ - $a$, all NA races are avirulent to $P g 10$, and only races NA1 and NA70 are virulent to $P g 6$.

\section{ACKNOWLEDGMENTS}

We thank K. Dunsmore, C. Leclerc, T. Zegeye, and $\mathrm{L}$. Wanschura for their technical assistance.

\section{LITERATURE CITED}

1. Adhikari, K. N., McIntosh, R. A., and Oates, J. D. 1999. Inheritance of the stem rust resistance phenotype $P g-a$ in oats. Euphytica 105:143154.

2. Adhikari, K. N., McIntosh, R. A., and Oates, J. D. 2000. Distribution and temperature sensitivities of genes for stem rust resistance in Australian oat cultivars and selected germplasm. Aust. J. Agric. Res. 51:75-83.

3. Bailey, D. L. 1925. Physiologic specialization in Puccinia graminis avenae Erikss. and Henn. Minn. Agric. Exp. Stn. Bull. 35.

4. Chong, J., Leonard, K. J., and Salmeron, J. J. 2000. A North American system of nomenclature for Puccinia coronata f. sp. avenae. Plant Dis. 84:580-585.

5. Fetch, T. G., Jr. 2003. Physiologic specialization of Puccinia graminis on wheat, barley, and oat in Canada in 2000. Can. J. Plant Pathol. 25:174-181.

6. Fetch, T. G., Jr. 2006. Effect of temperature on expression of seedling resistance in oats to Puccinia graminis f. sp. avenae. Can. J. Plant Pathol. 28:558-565.

7. Green, G. J. 1965. Stem rust of oats in Canada in 1964. Can. Plant Dis. Surv. 45:19-22.

8. Harder, D. E. 1994. Virulence dynamics of Puccinia graminis f. sp. avenae in Canada, 1921-1993. Phytopathology 84:739-746.

9. Harder, D. E. 1999. Usefulness of gene $\mathrm{Pg} 10$ as a source of stem rust resistance in oat breeding. Phytopathology 89:1214-1217.

10. Harder, D. E., Chong, J., Brown, P. D., and Martens, J. W. 1990. Inheritance of resistance to Puccinia coronata avenae and P. graminis avenae in an accession of Avena sterilis from Spain. Genome 33:198-202.

11. Levine, M. N., and Smith, D. C. 1937. Comparative reaction of oat varieties in the seedling and maturing stages to physiologic races of Puccinia graminis avenae and the distribution of these races in the United States. J. Agric. Res. 55:713-729.

12. Long, D. L., and Kolmer, J. A. 1989. A North American system of nomenclature for $P u c$ cinia recondita $\mathrm{f}$. $\mathrm{sp}$. tritici. Phytopathology 79:525-529.

13. Martens, J. W. 1985. Stem rust of oats. Pages 103-129 in: The Cereal Rusts: Volume II: Diseases, Distribution, Epidemiology, and Control. A. P. Roelfs and W. R. Bushnell, eds. Academic Press, New York.

14. Martens, J. W., Roelfs, A. P., McKenzie, R. I. H., Rothman, P. G., Stuthman, D. D., and Brown, P. D. 1979. System of nomenclature for pathotypes of Puccinia graminis f. sp. ave- nae. Phytopathology 69:293-294.

15. McKenzie, R. I. H., and Martens, J. W. 1968. Inheritance in the oat strain C.I. 3034 of adult plant resistance to race $\mathrm{C} 10$ of stem rust. Crop Sci. 60:625-627.

16. Newton, M., and Johnson, T. 1944. Physiologic specialization of oat stem rust in Canada Can. J. Res. 22:201-216.

17. Roelfs, A. P., and Martens, J. W. 1988. An international system of nomenclature for Puccinia graminis f. sp. tritici. Phytopathology 78:526-533

18. Sadanaga, K., and Simons, M. D. 1960. Transfer of crown rust resistance of diploid and tetraploid species to hexaploid oats. Agron. J. 52:285-288.

19. Simons, M. D., Martens, J. W., McKenzie, R. I. H., Nishiyama, I., Sadanaga, K., Sebesta, J. and Thomas, H. 1978. Oats: a standardized system of nomenclature for genes and chromosomes and catalog of genes governing characters. U. S. Dep. Agric. Handb. 509, Washington, DC.

20. Stakman, E. C., Levine, M. N., and Bailey, D. L. 1923. Biologic forms of Puccinia graminis on varieties of Avena spp. J. Agric. Res. 24:1013-1018.

21. Stewart, D. M., and Roberts, B. J. 1970. Identifying races of Puccinia graminis $\mathrm{f}$. sp. avenae. A modified international system. U. S. Dep. Agric. Tech. Bull. 1416. 